\title{
Induction of Apoptosis in the Human Prostate Cancer Cell Line DU-145 by a Novel Micronutrient Formulation
}

\author{
M. Waheed Roomi, Neha Shanker, Aleksandra Niedzwiecki*, Matthias Rath \\ Oncology Division, Dr. Rath Research Institute, Santa Clara, CA, USA \\ Email: a.niedz@drrath.com
}

Received 18 October 2014; revised 19 November 2014; accepted 9 December 2014

Copyright (C) 2015 by authors and Scientific Research Publishing Inc.

This work is licensed under the Creative Commons Attribution International License (CC BY). http://creativecommons.org/licenses/by/4.0/

c) (i) Open Access

\section{Abstract}

Prostate cancer, the most frequently diagnosed cancer in men, primarily affects males aged 55 and older and is more common in African Americans than Caucasians. Once the cancer has metastasized, current treatments are generally ineffective. We have identified a novel anti-neoplastic agent, a specifically designed nutrient mixture (NM), containing ascorbic acid, lysine, proline and green tea extract that demonstrates a broad spectrum of anti-tumor activity against a number of human cancer cell lines. In a previous study NM significantly inhibited prostate tumor in nude mice. In this study, we tested whether the formulation exerts its anti-tumor effects through induction of apoptosis on prostate cancer cell line DU-145. The effect of the nutrient mixture (NM) on cell growth inhibition in DU-145 cells was examined by 3-(4,5-dimethylthiazole-2-yl)-2,5-diphenyltetrazolium bromide (MTT) assay. Morphological changes and caspase activation associated with apoptosis induction was checked by H\&E staining and Live Green Caspase assay, respectively. The NM was found to be slightly toxic to DU-145 cells at $100 \mu \mathrm{g} / \mathrm{ml}$, but significantly toxic at $500 \mu \mathrm{g} / \mathrm{ml}$ and $1000 \mu \mathrm{g} / \mathrm{ml}$. Percentage of cells undergoing apoptosis also increased from $6 \%$ at $100 \mu \mathrm{g} / \mathrm{ml}$ to $49 \%$ at 500 $\mu \mathrm{g} / \mathrm{ml}$ and $83 \%$ at $1000 \mu \mathrm{g} / \mathrm{ml}$, with greater number of cells showing morphological changes such as condensed nuclei and an acidophilic cytoplasm at higher concentrations. For the purpose of comparison, NM was also tested on a normal human dermal fibroblast (NHDF) cell line which exhibited far less apoptosis induction as compared to DU-145 cells. The percentage of cells undergoing apoptosis in case of NHDF cells was $7 \%$ at $100 \mu \mathrm{g} / \mathrm{ml}, 25.6 \%$ at $500 \mu \mathrm{g} / \mathrm{ml}$ and $76.5 \%$ at $1000 \mu \mathrm{g} / \mathrm{ml}$. Our results demonstrate that the NM is effective in inhibiting cancer cell viability and inducing apoptosis in prostate cancer DU-145 cells and can thus be used as an effective treatment for prostate cancer.

\footnotetext{
"Corresponding author.
} 
Keywords

Prostate Cancer DU-145, NHDF, Apoptosis, Cytotoxicity, Caspase, MTT

\section{Introduction}

Prostate cancer, the leading non-cutaneous cancer and the second leading cause of death in men in the U.S., primarily affects males of age 55 and above and is more common in African American males than white males [1]. It accounted for approximately 15\% of all cancer diagnosis and $6.6 \%$ of all cancer deaths in men in 2012. According to the estimates of world cancer prevalence, prostate cancer is likely to contribute $25.6 \%$ of all the cancers in men in the next 5 years [2].

Standard treatment of prostate cancer consists of surgery (prostatectomy), hormonal therapy and radiotherapy. While prostatectomy is successful for treating early stage cancer, its use is limited to localized tumors and can cause nerve damage resulting in impotence, incontinence or rectal injury [3]-[5]. Hormonal therapy acts by blocking the action of cancer supporting male hormones and is only effective till the time the cancer can spread independent of male hormones [6] [7]. Similarly, radiotherapy is also effective for early stage prostate cancer and becomes progressively ineffective in later stages. Thus, while prostate carcinomas are initially responsive to surgery and hormonal therapies when localized, they eventually become more aggressive and unresponsive to standard treatments.

Due to the limitations of the current treatment modalities in tackling prostate cancer, there is an urgent need for safe and effective therapeutic approaches. Epidemiological studies have suggested that consumption of a plant based diet has been associated with the prevention of cancer. Diet and nutritional supplementation have often been analyzed by several studies for beneficial effect on prostate cancer attenuation [8] [9]. Several studies have also implicated the phytochemicals and micro nutrients such as epigallocatechin gallate (EGCG—present in green tea), ascorbic acid, $\mathrm{N}$-acetyl cysteine and selenium individually have anti-cancer properties. However, a study combining the micronutrients in the appropriate quantities for synergistic and enhanced action is lacking.

We have developed strategies to inhibit cancer development and its spread by using naturally occurring nutrients such as ascorbic acid, green tea extract, lysine and proline in a unique combination. This unique nutrient mixture (NM) demonstrates a broad spectrum of anti-tumor activity against a number of human cancer cell lines. In a previous study we found that NM significantly inhibited prostate tumors in nude mice. In this study we investigated in a DU-145 prostate cancer cell line whether the inhibition of prostate tumors by NM was due to induction of apoptosis.

The anti-proliferative and apoptotic effect of NM was determined in vitro by checking for the loss of cell viability, cell morphology changes and caspase activation in human prostate DU-145 cells. Apoptosis induction was also analyzed in normal cells represented by human dermal fibroblasts upon treatment with the NM to check for distinct effects on cancer and normal cells.

\section{Materials and Methods}

\subsection{Composition of the Nutrient Mixture}

The stock solution of the nutrient mixture (total weight $4.4 \mathrm{~g}$ ) used for testing was composed of the following in the quantities indicated: Vitamin C (as ascorbic acid and as Mg, Ca and Palmitate ascorbate) $700 \mathrm{mg}$, L-lysine 1000 mg; L-proline 750 mg; L-arginine 500 mg, N-acetyl cysteine $200 \mathrm{mg}$; standardized green tea extract 1000 mg (derived from green tea leaves, was obtained from US Pharma Lab; the certificate of analysis indicated the following characteristics: total polyphenol: 80\%, Catechins: 60\%; Epigallocatechin gallate (EGCG): 35\% and Caffeine: 1\%), selenium $30 \mu \mathrm{g}$, copper $2 \mathrm{mg}$, manganese $1 \mathrm{mg}$.

\subsection{Cells and Cell Culture}

Human prostate cancer cell line DU-145 and normal human dermal fibroblasts (NHDF) were obtained from ATCC (American Type Culture Collection, Rockville, MD, USA) and maintained in Dulbecco's Modified Eagle's Medium (DMEM) and supplemented with 10\% FBS, $100 \mathrm{U} / \mathrm{ml}$ penicillin and $100 \mu \mathrm{g} / \mathrm{ml}$ streptomycin. 
The media and sera were obtained from ATCC, and antibiotics from Gibco BRL (Long Island, NY, USA). The cells were grown at $37^{\circ} \mathrm{C}$ in $5 \% \mathrm{CO}_{2}$.

\subsection{MTT Cytotoxicity Assay}

Cell viability was evaluated by MTT assay, a colorimetric assay based on the ability of viable cells to reduce a soluble yellow tetrazolium salt (3-[4,5-dimethylthiazol-2-yl]-2,5-diphenyltetrazolium bromide) to a blue formazan crystal by mitochondrial succinate dehydrogenase activity of viable cells. This test is a good index of mitochondrial activity and thus of cell viability. Briefly, cell suspensions were plated in 24-well tissue culture plates (Nunc, Denmark) at a concentration of $3 \times 10^{4}$ cells/well. After incubating the plates for 24 hours at $37^{\circ} \mathrm{C}$ in a humidified incubator, the cells were treated with the nutrient mixture at concentrations of 100, 500 and 1000 $\mu \mathrm{g} / \mathrm{ml}$ for 24 hours or left untreated in the control group. $500 \mu \mathrm{l}$ of MTT assay reagent (Sigma No. M-2128-0.5 $\mathrm{mg} / \mathrm{ml}$ in media) was added to each well followed by 2-hour incubation at $37^{\circ} \mathrm{C}$. Following incubation, the solution was carefully aspirated from the wells, the formazan product was dissolved in $1 \mathrm{ml}$ DMSO and the absorbance (OD) was measured on a microplate reader at a wavelength of $570 \mathrm{~nm}$ in BioSpec 1601, Shimadzu spectrometer. The $\mathrm{OD}_{570}$ of the DMSO solution in each well was considered to be proportional to the number of cells. The $\mathrm{OD}_{570}$ of the control (treatment without supplement) was considered to be $100 \%$.

\subsection{Live Green Caspase Assay}

The cells were grown to confluence and either left in media alone or challenged with the NM dissolved in media at 100, 500 and $1000 \mu \mathrm{g} / \mathrm{ml}$ and incubated for 24 hours. The cell culture was washed with PBS and treated with the caspase reagent as specified in the manufacturer's protocol (Molecular Probes Image-IT Live Green Poly Caspases Detection Kit 135104, Invitrogen). The cells were photographed under the fluorescence microscope and counted. Green colored cells represent viable cells, while orange and red colors represent early and late apoptotic cells respectively.

\subsection{H \& E Staining of Cells}

The cells were cultured in 24-well plates and were either kept untreated or treated with NM in test concentrations of 100, 500 and $1000 \mu \mathrm{g} / \mathrm{ml}$. After 24 hour incubation, the cells were washed with PBS, fixed with cold methanol and then stained with haematoxylin and eosin for 5 min each. The stained cells were then observed and imaged by microscopy.

\subsection{Statistical Analysis}

The results were expressed as mean \pm standard deviation (SD) for the groups. Data was analyzed by the independent t-test.

\section{Results}

\subsection{Nutrient Mixture Decreased the Viability of Prostate Cancer Cells}

To determine whether the nutrient formulation is cytotoxic to prostate cancer cells DU-145, we used the MTT assay to check for cell viability at various NM dosages. The cells in the control group were left untreated and those in the test group were treated with 100, 500 and $1000 \mu \mathrm{g} / \mathrm{ml}$ of nutrient mixture for $24 \mathrm{hr}$. Our results demonstrated that the nutrient formulation can induce cell death in the prostate cancer cells in a dose dependent manner after 24 hours of incubation. As can be seen in Figure 1, the cell viability showed a significant dose dependent decrease with $84 \% \pm 6 \%$ viable cells at $100 \mu \mathrm{g} / \mathrm{ml} \mathrm{NM}, 63 \% \pm 12 \%$ at $500 \mu \mathrm{g} / \mathrm{ml} \mathrm{NM}$ and $53 \% \pm 4 \%$ at $1000 \mu \mathrm{g} / \mathrm{ml} \mathrm{NM}$, respectively, as compared to the untreated control group.

\subsection{Nutrient Mixture Induced Apoptosis through Induction of Caspases}

Quantitative analysis of DU-145 cells in early and late apoptotic stages was done by using the Live Green Caspase assay. Analysis with Live Green Caspase detection kit revealed a dose dependent increase in apoptosis of DU-145 cells with slight apoptosis found at $100 \mu \mathrm{g} / \mathrm{ml}$, moderate at $500 \mu \mathrm{g} / \mathrm{ml}$ and significant at $1000 \mu \mathrm{g} / \mathrm{ml}$ 


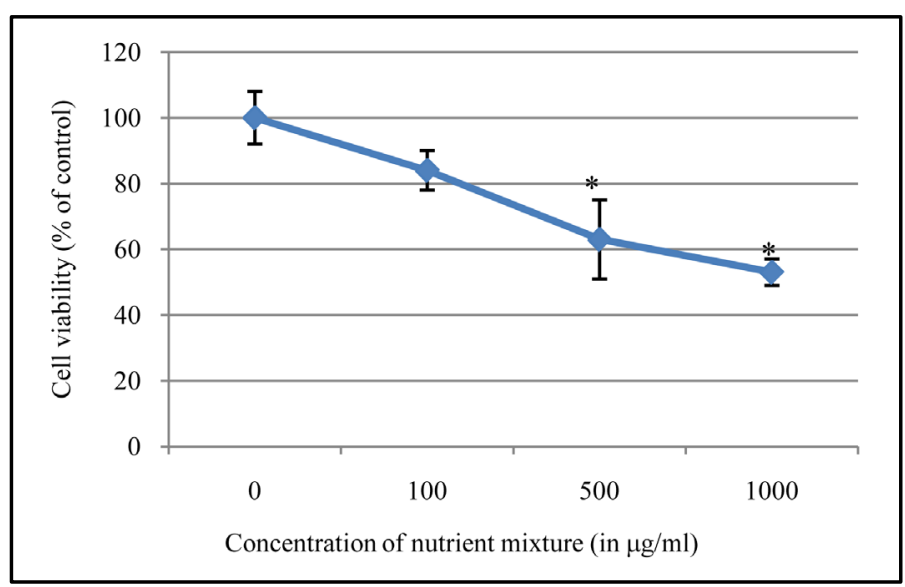

Figure 1. Effect of NM on cell viability: MTT assay using prostate cancer DU-145 cells treated with (a) $0 \mu \mathrm{g} / \mathrm{ml}$, (b) $100 \mu \mathrm{g} / \mathrm{ml}$, (c) 500 $\mu \mathrm{g} / \mathrm{ml}$, (d) $1000 \mu \mathrm{g} / \mathrm{ml}$ concentrations of NM respectively ( $<0.01)$.

NM. Quantitative analysis of the data revealed the percentage of apoptotic cells to be $6 \%$ at $100 \mu \mathrm{g} / \mathrm{ml}$ (all in early phase apoptosis), $49 \%$ at $500 \mu \mathrm{g} / \mathrm{ml}(10 \%$ in early phase; $39 \%$ in late phase) and $83 \%$ for $1000 \mu \mathrm{g} / \mathrm{ml} \mathrm{NM}$ ( $8 \%$ in early phase; $75 \%$ in late phase). It was observed that there was a corresponding decrease in percentage of live cells and an increase in percentage of cells in late apoptotic stages with increasing NM concentrations. A quantitative analysis of apoptosis induction in normal human dermal fibroblasts showed equivalency to DU-145 cells at $100 \mu \mathrm{g} / \mathrm{ml}$. However, at higher concentrations of NM the induction of apoptosis was significantly lower in NHDF cells as compared to DU-145 cells. The percentage of apoptotic NHDF cells was $7 \%$ at $100 \mu \mathrm{g} / \mathrm{ml}(2 \%$ in early phase, $5 \%$ in late phase), $25.6 \%$ at $500 \mu \mathrm{g} / \mathrm{ml}$ ( $4.6 \%$ in early phase, $21 \%$ in late phase) and $76.5 \%$ at $1000 \mu \mathrm{g} / \mathrm{ml}$ (23.5\% in early phase, $53 \%$ in late phase). Photomicrographs of apoptotic DU-145 cells and NHDF are shown in Figures 2(a)-(d) and Figures 3(a)-(d), respectively. The quantitative analysis of live, early and late DU-145 prostate cancer cells and NHDF cells are shown in Figure 2(e) and Figure 3(e), respectively.

\subsection{Nutrient Mixture Induced Morphological Changes Associated with Apoptosis}

The DU-145 cells were stained by using H \& E to detect apoptotic cells which show the characteristic morphological changes such as the shrinkage of the cytoplasm and darkly stained nuclei with intensely acidophilic cytoplasm. H \& E staining of DU-145 cells treated with the nutrient formulation showed that with increasing concentrations of NM the cells showed extensive cell shrinkage, rounding and nuclear condensation (Figure 4). The changes were dose dependent, increasing in intensity with increasing NM concentrations.

\section{Discussion}

The stimulation of suppressed apoptotic pathways in cancer cells and the induction of apoptosis is a predominant mechanistic approach to target cancer. It has previously been reported that NM inhibited prostate tumor growth in xenografts [10]. In this study we analyzed whether the tumor inhibitory effect may be due to the cytotoxic and apoptotic effect of NM treatment on DU-145 prostate cancer cells.

The cytotoxic effect of NM on prostate cancer cell line DU-145 was evident from the significant dose dependent increase in cytotoxicity that was observed with increasing NM concentrations. The cell viability showed a substantial decrease from $84 \% \pm 6 \%$ at $100 \mu \mathrm{g} / \mathrm{ml}$ to $63 \% \pm 12 \%$ at $500 \mu \mathrm{g} / \mathrm{ml}$ and $53 \% \pm 4 \%$ at $1000 \mu \mathrm{g} / \mathrm{ml}$. Thus, the NM is capable of inhibiting cell viability in a dose dependent fashion.

Activation of caspase enzymes is a distinctive feature of the early stages of apoptosis and these enzymes participate in a series of reactions that are triggered in response to pro-apoptotic signals and result in the cleavage of protein substrates and in the subsequent disassembly of the cell. Upon treatment with 100, 500 and $1000 \mu \mathrm{g} / \mathrm{ml}$ NM, activated caspases were detected. A dose dependency was seen in the activation of caspases and induction of apoptosis, with cells progressing from $6 \%$ in early stage apoptosis at $100 \mu \mathrm{g} / \mathrm{ml}$ to $49 \%$ at $500 \mu \mathrm{g} / \mathrm{ml}$ and to $83 \%$ at $1000 \mu \mathrm{g} / \mathrm{ml} \mathrm{NM}$ concentration. A dose dependent induction of apoptosis was also observed in case of 


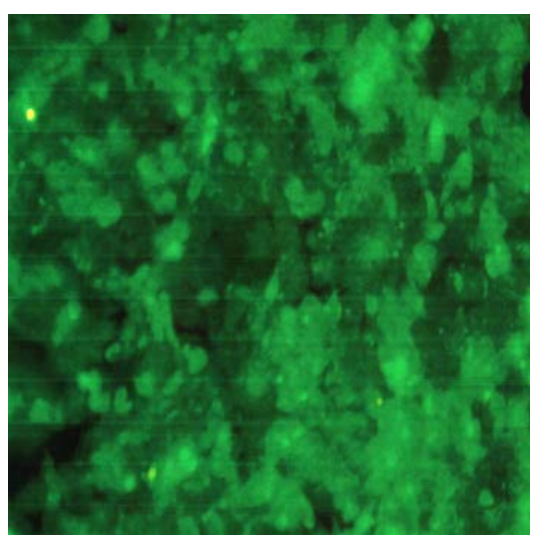

(a)

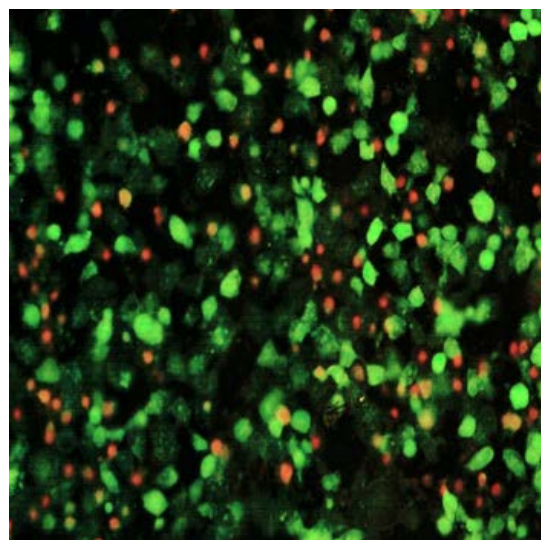

(c)

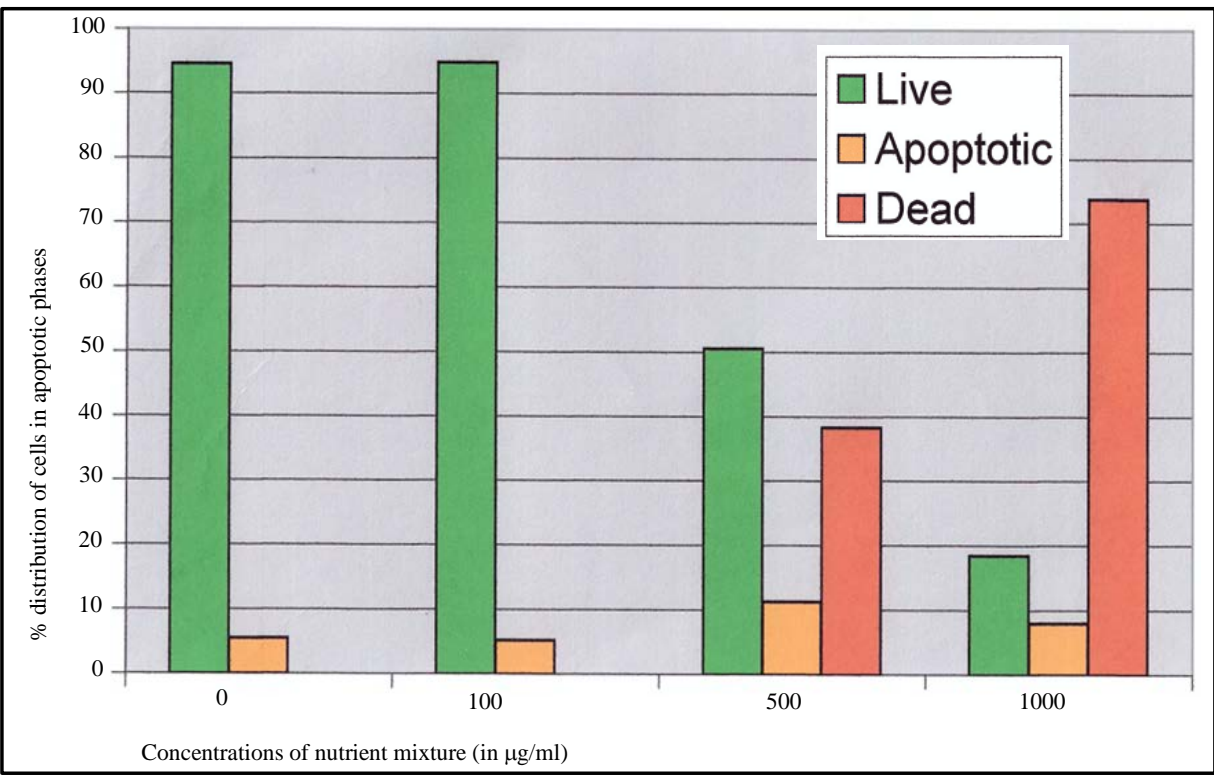

(e)

Figure 2. Effect of NM on induction of apoptosis in prostate cancer DU-145 cells. Photomicrographs of DU-145 cells (×20 magnification) treated with (a) $0 \mu \mathrm{g} / \mathrm{ml}$, (b) $100 \mu \mathrm{g} / \mathrm{ml}$, (c) 500 $\mu \mathrm{g} / \mathrm{ml}$, (d) $1000 \mu \mathrm{g} / \mathrm{ml}$ concentrations of NM respectively. (e) Analytical representation of the differential distribution of cells in early or late phases of apoptosis upon treatment with 0,100 , 500 and $1000 \mu \mathrm{g} / \mathrm{ml} \mathrm{NM}$ concentrations.

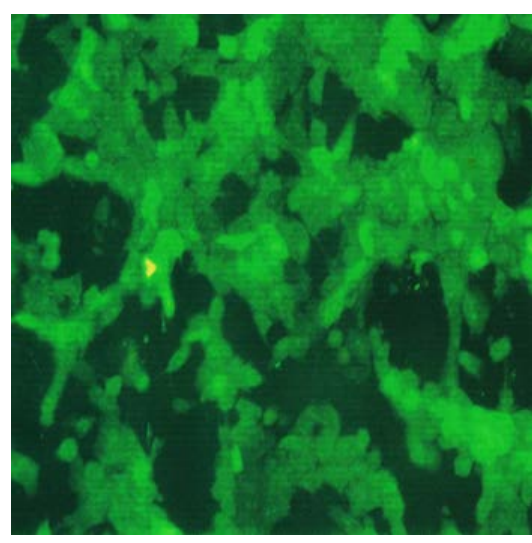

(b)

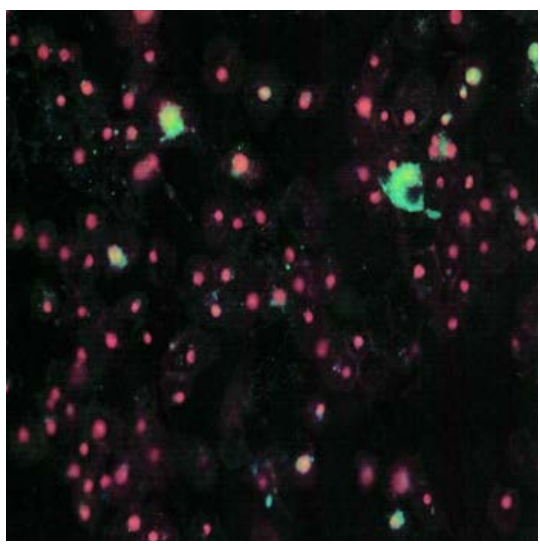

(d) 


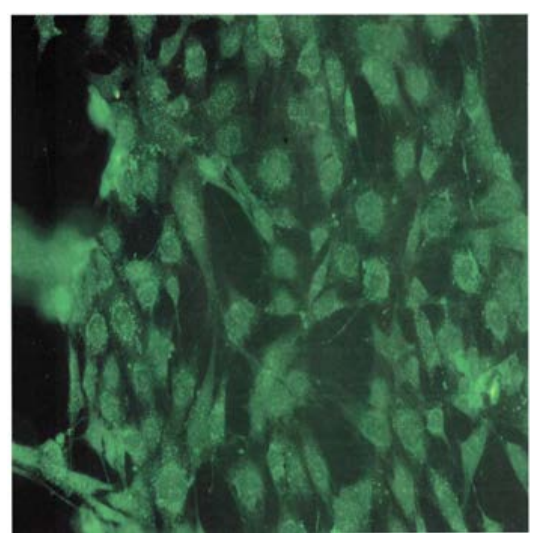

(a)

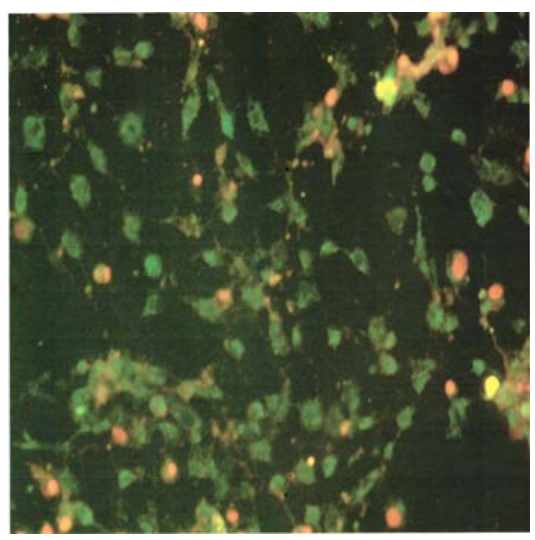

(c)

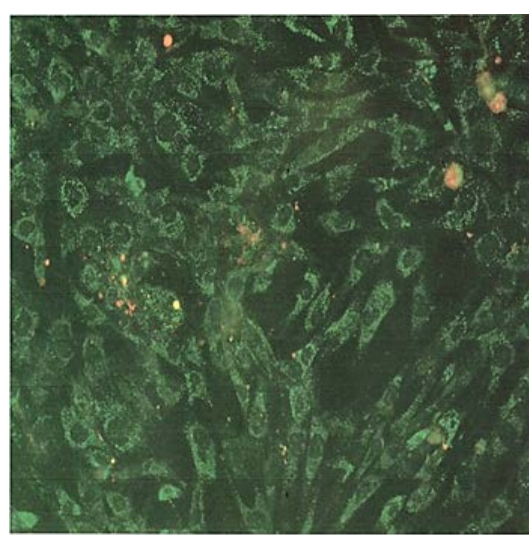

(b)

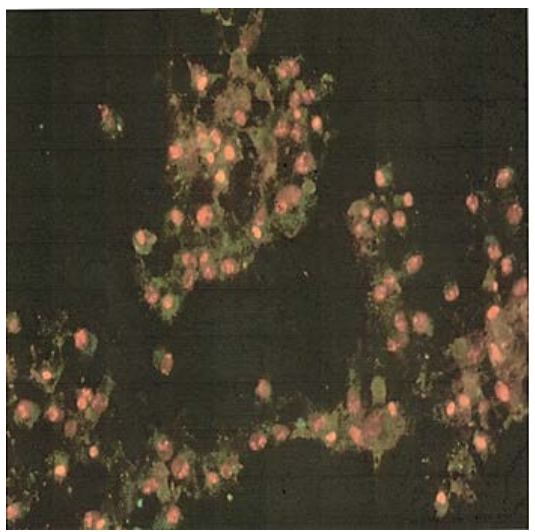

(d)

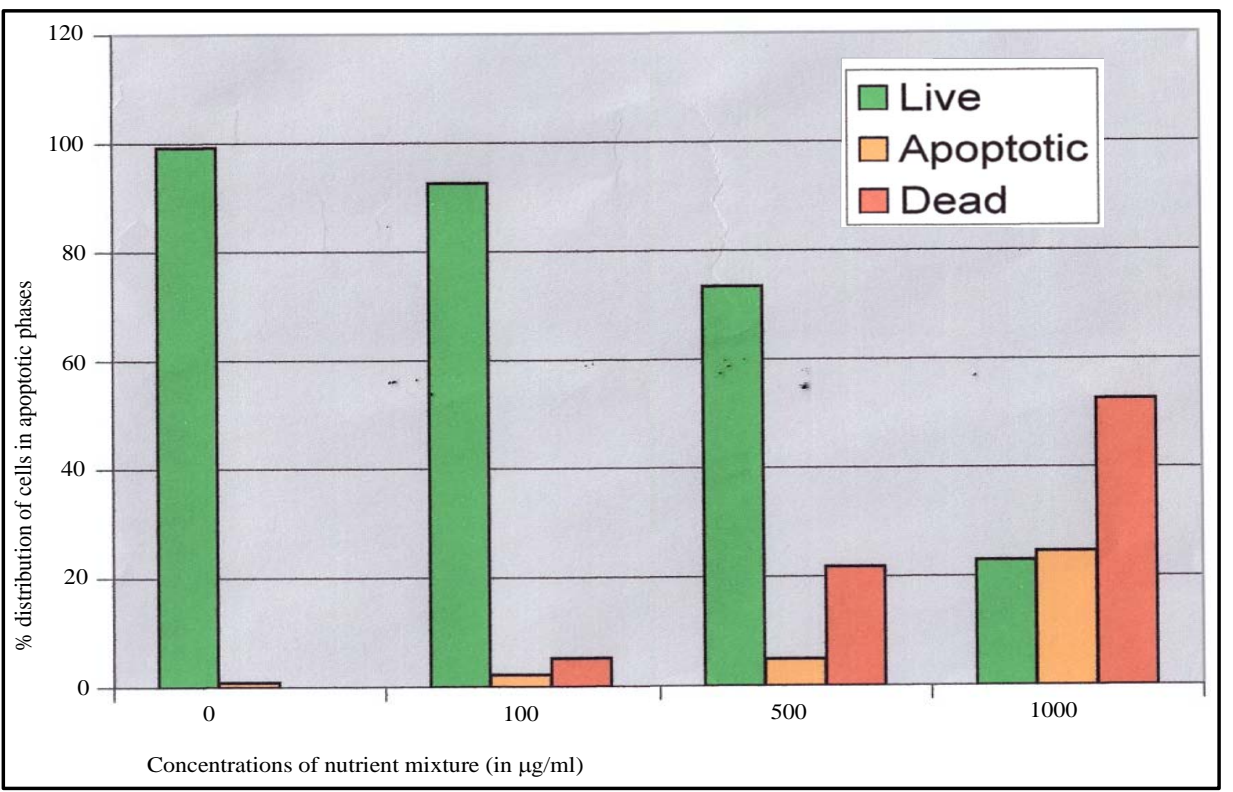

(e)

Figure 3. Effect of NM on induction of apoptosis in normal NHDF cells. Photomicrographs of NHDF cells (×20 magnification) treated with (a) $0 \mu \mathrm{g} / \mathrm{ml}$, (b) $100 \mu \mathrm{g} / \mathrm{ml}$, (c) $500 \mu \mathrm{g} / \mathrm{ml}$, (d) 1000 $\mu \mathrm{g} / \mathrm{ml}$ concentrations of NM respectively. (e) Analytical representation of the differential distribution of cells in early or late phases of apoptosis upon treatment with $0,100,500$ and 1000 $\mu \mathrm{g} / \mathrm{ml}$ NM concentrations. 


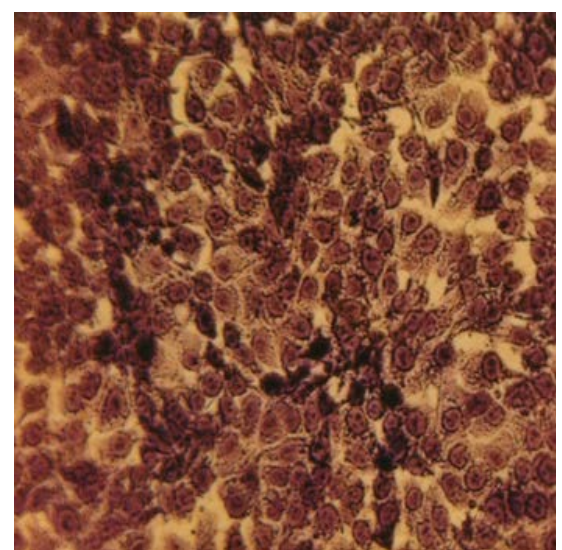

(a)

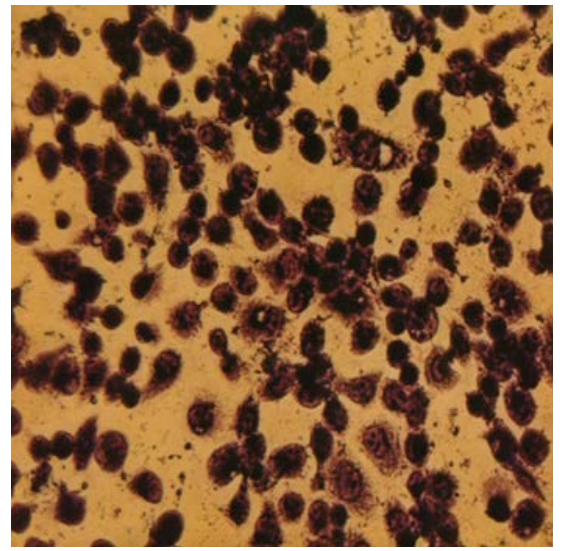

(c)

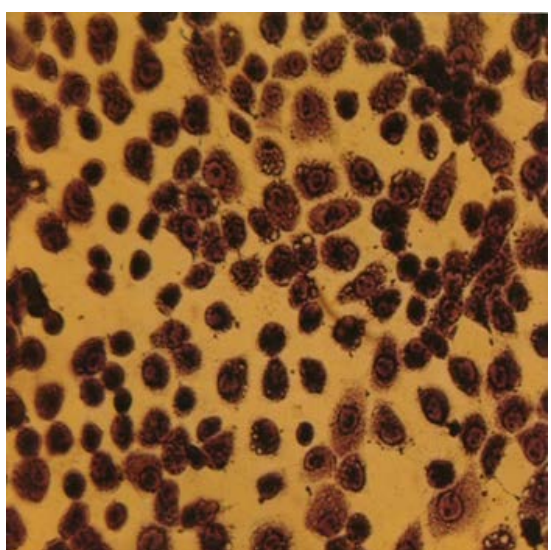

(b)

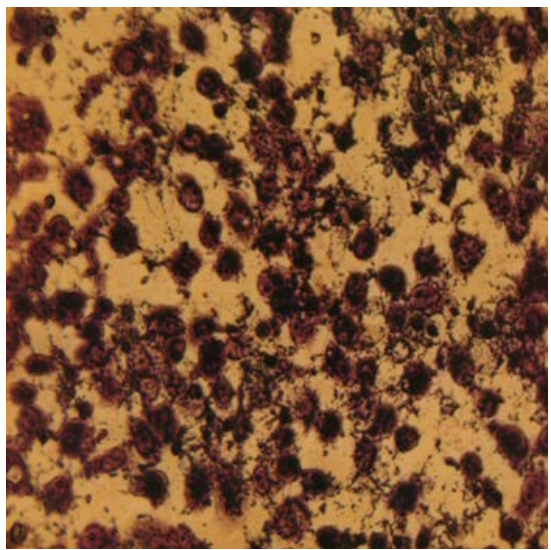

(d)

Figure 4. Effect of NM on morphological changes: H \& E staining of prostate cancer DU-145 cells treated with (a) $0 \mu \mathrm{g} / \mathrm{ml}$, (b) $100 \mu \mathrm{g} / \mathrm{ml}$, (c) $500 \mu \mathrm{g} / \mathrm{ml}$, (d) $1000 \mu \mathrm{g} / \mathrm{ml}$ concentrations of NM respectively.

NHDF cells treated with increasing concentrations of NM. While the percentage of apoptotic cells was $7 \%$ at $100 \mu \mathrm{g} / \mathrm{ml}$, it increased to $25.6 \%$ at $500 \mu \mathrm{g} / \mathrm{ml}$ and to $76.5 \%$ at $1000 \mu \mathrm{g} / \mathrm{ml} \mathrm{NM}$.

Morphological changes characteristic of apoptotic cells such as cell shrinkage, nuclear compaction, loss of membrane symmetry and condensation of the cytoplasm were also analyzed. Upon treatment of DU-145 prostate cancer cells with 100, 500 and $1000 \mu \mathrm{g} / \mathrm{ml}$ of $\mathrm{NM}$, it was found that the progressive rounding of cells and nuclear condensation showed a dose dependent increase.

From the results, it can thus be seen that at $100 \mathrm{ug} / \mathrm{ml} \mathrm{NM}$ a very small percentage of cells showed cytotoxicity (16\%), apoptosis induction (6\%) and morphological changes. On the other hand, at $500 \mu \mathrm{g} / \mathrm{ml} \mathrm{NM}$, significant cytotoxicity (37\%) and apoptosis induction (49\%) was observed. At $1000 \mu \mathrm{g} / \mathrm{ml} \mathrm{NM}$, apoptosis induction (83\%) and cytotoxicity (47\%) were even higher. The NHDF cells in turn showed a lower induction of apoptosis as compared to the prostate cancer DU-145 cells, especially at higher treatment doses. A comparison of apoptosis induction at $500 \mu \mathrm{g} / \mathrm{ml}$ and $1000 \mu \mathrm{g} / \mathrm{ml} \mathrm{NM}$ revealed a $23.4 \%$ and $6.5 \%$ lesser percentage of apoptotic NHDF cells as compared to DU-145 cells. It can thus be inferred that the effective concentration of NM would ideally be $500 \mu \mathrm{g} / \mathrm{ml}$ which can induce apoptosis through caspase activation in a significant number of cancer cells while not significantly effect of normal cells.

The nutrient formulation used in the study was specifically developed to combine the individual anti-tumorigenic and pro-apoptotic properties of the component micronutrients. The inhibitory effects of the individual nutrients comprising the novel nutrient formulation have been reported in both experimental and clinical studies. Ascorbic acid is increasingly recognized as an agent with broad biological function. Among its well-known functions are its antioxidant and free radical scavenging functions and detoxification of exogenous compounds 
[11]. Previous studies have described the mechanisms of action of ascorbic acid in cancer prevention [12]-[15], including a role in collagen synthesis and basement membrane integrity and hyaluronidase inhibition [16] [17], which may be important in inhibiting tumor spread and micrometastases. It has also been linked to the induction of both necrosis and apoptosis in prostate cancer [18].

Green tea has been shown to have chemopreventive and protective effects on prostate cancer incidence in a case controlled study in China [19] and a proof of principle study in Italy [20]. The green tea catechins such as (-)-epigallocatechin-3-gallate (EGCG), (-)-epigallocathechin (EGC), (-)-epicatechin-3-gallate (ECG), and (-)epicatechin (EC) have been proven to be chemopreventive agents in vitro and in many in vivo animal models of induced carcinogenesis [21] [22]. EGCG on its own is also a potent anti-cancer agent and has been reported to have a growth inhibitory effect against certain human cancer cell lines [23]-[25].

Supplementation with micronutrients such as selenium, studied alone in intervention trials [26]-[29] has shown chemopreventive effects in prostate cancer. Even in combination with other nutrients, selenium has been shown to have chemopreventive effects in prostate and colorectal cancer [30].

The nutrient mixture was formulated based on a number of studies conducted in our lab to test various combinations of micronutrients. The selection of a particular formulation was dependent on demonstration of significant synergy in inhibiting cancer progression and metastasis. It has been observed in previous studies that a combination of nutrients such as ascorbic acid, EGCG, lysine and proline show a synergistic anticancer effect which is much more effective than any of the individual nutrients alone [31].

The NM has also proven to be effective in inhibiting a variety of other cancer types which has been demonstrated by both in vitro and in vivo studies. As seen in Table 1, tumor growth in a variety of tumor types was inhibited by treatment with $\mathrm{NM}$ in diet. While a reduction in tumor weight of $42 \%$ was observed in hepatocellular carcinoma SK-Hep-1 xenografts [32], it went down by 59\% in cervical HeLa [33] and 63\% in colon HCT-116 xenografts [34]. Similar results were obtained with in vitro cancer models in which $1000 \mu \mathrm{g} / \mathrm{ml} \mathrm{NM}$ resulted in growth inhibition of various cancer cell lines as seen in Table 2. The breast cancer cell line MDA-MB-231 [35] showed a growth inhibition of 50\%, while melanoma A2058 [36] and liposarcoma SW-872 [37] showed inhibition of $64 \%$ and $61 \%$, respectively. A relatively lower growth inhibition was seen in the osteosarcoma cell line MNNG which showed an inhibition of only $10 \%$ [38].

In positive correlation with the results of this study, the prostate cancer cell line LNCaP showed a growth inhibition of $80 \%$ [39] while prostate cancer PC-3 xenografts showed a reduction in tumor weight by $47 \%$ [10]. NM has also been substantiated by other prostate cancer studies that demonstrate its effectivity in inhibiting MMP expression, invasion and migration of LNCap and DU-145 cells [39]. Thus, treatment with NM can serve

\begin{tabular}{cc|}
\hline Table 1. Inhibition of tumor weight by NM in various cancer cell xenografts. \\
\hline Cancer cell type & Reduction of tumor weight by NM diet over control diet \\
\hline Prostate PC-3 & $47 \%(\mathrm{p}<0.0001)$ \\
Hepatocellular carcinoma & $42 \%(\mathrm{p}=0.09)$ \\
Colon HCT-116 & $63 \%(\mathrm{p}=0.0002)$ \\
Cervical HeLa & $59 \%(\mathrm{p}=0.001)$ \\
Lung A549 & $44 \%(\mathrm{p}=0.001)$ \\
\hline
\end{tabular}

Table 2. Inhibition of cancer cell proliferation upon treatment with NM.

\begin{tabular}{cc}
\hline Cancer cell type & \% Inhibition of cell growth at $\mathbf{1 0 0 0} \boldsymbol{\mu g} / \mathbf{m l ~ N M}$ \\
\hline Prostate LNCaP & $80 \%$ \\
Ostescarcoma $\mathrm{U}_{2} \mathrm{OS}$ & $60 \%$ \\
Liposarcoma SW-872 & $61 \%$ \\
Breast MDA-MB-231 & $50 \%$ \\
Osteosarcoma MNNG & $10 \%$ \\
\hline
\end{tabular}


as a multipronged approach to target prostate cancer.

The results of the present study showed that supplementation with NM was effective in inhibiting proliferation of prostate cancer cells by inducing apoptosis using a caspase dependent mechanism. The severity of apoptosis showed dose dependence, increasing with increasing concentrations of NM. Interestingly, a comparison of apoptosis induction in normal human dermal fibroblasts and prostate cancer DU-145 cells suggested a decreased apoptotic effect of the NM on normal cells, thereby supporting the hypothesis of preferential inhibition of prostate cancer cells.

Though a validation of the effectivity of the NM for different cancers and a selection of therapeutic dose can only be obtained upon testing the response of each cancer type and dose individually, in the absence of effective therapies for prostate cancer treatment, the novel nutrient formulation offers a good alternative. In contrast to the toxic side effects of chemotherapy, the NM has also proven to be a safe therapeutic agent. In a previous study addressing safety issues, we found that gavaging adult female ODS rats (weighing 250 - 300 g) with the NM (at 30, 90, or $150 \mathrm{mg}$ per day for 7 days) had no adverse effects on either of the vital organs (heart, liver, kidney) or on the associated functional serum enzymes. This indicates that the mixture is safe to use even at these high doses, which far exceed the normal equivalent dosage [40]. In light of the above fact and based on the results in this study, the NM shows promise and offers a good alternative to chemotherapy in the treatment of prostate cancer.

\section{Acknowledgements}

This research study was funded by Dr. Rath Foundation (Santa Clara, CA, USA), a non-profit organization. Dr. Bilwa Bhanap and Cathy Flowers provided proofreading assistance.

\section{Conflicts of Interest}

The authors have declared that they have no competing interest.

\section{References}

[1] Crawford, E.D. (2003) Epidemiology of Prostate Cancer. Urology, 62, S3-S12. http://dx.doi.org/10.1016/j.urology.2003.10.013

[2] Stewart, B.W. and Wild, C.P., Eds. (2014) World Cancer Report 2014. International Agency for Research on Cancer, Lyon.

[3] Bishoff, J.T., Motley, G., Optenberg, S.A., Stein, C.R., Monn, K.A., Browning, S.M., Sabanagh, E., Foley, J.P. and Thompson, I.M. (1998) Incidence of Fecal and Urinary Incontinence Following Radical Perineal and Retropubic Prostatectomy in a National Population. The Journal of Urology, 160, 454-458. http://dx.doi.org/10.1016/S0022-5347(01)62924-0

[4] Melman, A., Boczko, J., Figueroa, J. and Leung, A.C. (2004) Critical Surgical Techniques for Radical Perineal Prostatectomy. The Journal of Urology, 171, 786-790. http://dx.doi.org/10.1097/01.ju.0000107834.23316.59

[5] Talcott, J.A., Manola, J., Clark, J.A., Kaplan, I., Beard, C.J., Mitchell, S.P., Chen, R.C., O’ Leary, M.P., Kantoff, P.W. and D'Amico, A.V. (2003) Time Course and Predictors of Symptoms after Primary Prostate Cancer Therapy. Journal of Clinical Oncology, 21, 3979-3986. http://dx.doi.org/10.1200/JCO.2003.01.199

[6] National Cancer Institute (2002) What You Need to Know about Prostate Cancer. http://www.cancer.gov/cancerinfo/wyntk/prostate.

[7] Conde, F.A. and Aronson, W.J. (2003) Risk Factors for Male Osteoporosis. Urologic Oncology, 21, 380-383. http://dx.doi.org/10.1016/S1078-1439(03)00109-1

[8] Hori, S., Butler, E. and McLoughlin, J. (2011) Prostate Cancer and Diet: Food for Thought? British Journal of Urology International, 107, 1348-1359. http://dx.doi.org/10.1111/j.1464-410X.2010.09897.x

[9] Willis, M.S. and Wians Jr., F.H. (2003) The Role of Nutrition in Preventing Prostate Cancer: A Review of the Proposed Mechanism of Action of Various Dietary Substances. Clinica Chimica Acta, 330, 57-83. http://dx.doi.org/10.1016/S0009-8981(03)00048-2

[10] Roomi, M.W., Ivanov, V., Kalinovsky, T., Niedzwiecki, A. and Rath, M. (2005) In Vivo Anti-Tumor Effect of Ascorbic Acid, Lysine, Proline and Green Tea Extract on Human Prostate Cancer PC-3 Xenografts in Nude Mice: Evaluation of Tumor Growth and Immunohistochemistry. In Vivo, 19, 179-183.

[11] Hodges, R.E. (1980) Ascorbic Acid. In: Goodhart, R.S. and Shils, M.E., Eds., Modern Nutrition in Health and Disease, 
6th Edition, Lea and Febiger, Philadelphia, 259-273.

[12] Levine, M. (1986) New Concepts in the Biology and Biochemistry of Ascorbic Acid. New England Journal of Medicine, 314, 892-902. http://dx.doi.org/10.1056/NEJM198604033141407

[13] Block, G. and Menkes, M. (1989) Ascorbic Acid in Cancer Prevention. In: Moon, T.E. and Micozzi, M.S., Eds., Diet and Cancer Prevention, Investigating the Role of Micronutrients, Marcel Dekker, Inc., New York, 341-388.

[14] Block, G. (1991) Vitamin C and Cancer Prevention: The Epidemiologic Evidence. American Journal of Clinical Nutrition, 53, 270S-282S.

[15] Hanck, A.B. (1988) Vitamin C and Cancer. Progress in Clinical and Biological Research, 259, 307-320.

[16] Cameron, E. and Pauling, L. (1973) Ascorbic Acid and the Glycosaminoglycans: An Orthomolecular Approach to Cancer and Other Diseases. Oncology, 27, 181-192. http://dx.doi.org/10.1159/000224733

[17] Cameron, E. and Pauling, L. (1974) The Orthomolecular Treatment of Cancer I. The Role of Ascorbic Acid in Host Resistance. Chemico-Biological Interactions, 9, 273-283. http://dx.doi.org/10.1016/0009-2797(74)90018-0

[18] Taper, H.S., Jamison, J.M., Gilloteaux, J., Gwin, C.A., Gordon, T. and Summers, J.L. (2001) In Vivo Reactivation of DNases in Implanted Human Prostate Tumors after Administration of a Vitamin $\mathrm{C} / \mathrm{K}_{3}$ Combination. Journal of Histochemistry and Cytochemistry, 49, 109-119. http://dx.doi.org/10.1177/002215540104900111

[19] Jian, L., Xie, L.P., Lee, A.H. and Binns, C.W. (2004) Protective Effect of Green Tea against Prostate Cancer: A CaseControl Study in Southeast China. International Journal of Cancer, 108, 130-135. http://dx.doi.org/10.1002/ijc.11550

[20] Bettuzzi, S., Brausi, M., Rizzi, F., Castagnetti, G., Peracchia, G. and Corti, A. (2006) Chemoprevention of Human Prostate Cancer by Oral Administration of Green Tea Catechins in Volunteers with High-Grade Prostate Intraepithelial Neoplasia: A Preliminary Report from a One-Year Proof of Principle Study. Cancer Research, 66, 1234-1240. http://dx.doi.org/10.1158/0008-5472.CAN-05-1145

[21] Liao, S., Kao, Y.H. and Hiipakka, R.A. (2001) Green Tea: Biochemical and Biological Basis for Health Benefits. Vitamins and Hormones, 62, 1-94. http://dx.doi.org/10.1016/S0083-6729(01)62001-6

[22] Liao, S., Umekita, Y., Guo, J., Kokontis, J.M. and Hiipakka, R.A. (1995) Growth Inhibition and Regression of Human Prostate and Breast Tumors in Athymic Mice by Tea Epigallocatechin Gallate. Cancer Letters, 96, 239-243. http://dx.doi.org/10.1016/0304-3835(95)03948-V

[23] Valcic, S., Timmerman, B.N., Alberts, D.S., Wachter, G.A., Krutzch, M., Wymer, J. and Guillen, J.M. (1996) Inhibitory Effects of Six Green Tea Catechins and Caffeine on the Growth of Four Selected Human Tumor Cell Lines. Anticancer Drugs, 7, 461-468. http://dx.doi.org/10.1097/00001813-199606000-00011

[24] Mukhtar, H. and Ahmed, N. (2000) Tea Polyphenols: Prevention of Cancer and Optimizing Health. American Journal of Clinical Nutrition, 71, 1698S-1720S.

[25] Yang, G.Y., Liao, J., Kim, K., Yurkow, E.J. and Yang, C.S. (1998) Inhibition of Growth and Induction of Apoptosis in Human Cancer Cell Lines by Tea Polyphenols. Carcinogenesis, 19, 611-616. http://dx.doi.org/10.1093/carcin/19.4.611

[26] Clark, L.C., Dalkin, B., Krongrad, A., Combs Jr., G.F., Turnbull, B.W., Slate, E.H., et al. (1998) Decreased Incidence of Prostate Cancer with Selenium Supplementation: Results of a Double-Blind Cancer Prevention Trial. British Journal of Urology, 81, 730-734.

[27] Duffield-Lillico, A.J., Dalkin, B.L., Reid, M.E., Turnbull, B.W., Slate, E.H., Jacobs, E.T., et al. (2003) Selenium Supplementation, Baseline Plasma Selenium Status and Incidence of Prostate Cancer: An Analysis of the Complete Treatment Period of the Nutritional Prevention of Cancer Trial. British Journal of Urology International, 91, 608-612. http://dx.doi.org/10.1046/j.1464-410X.2003.04167.x

[28] Marshall, J.R., Tangen, C.M., Sakr, W.A., Wood, D.P., Berry, D.L., Klein, E.A., et al. (2011) Phase III Trial of Selenium to Prevent Prostate Cancer in Men with High Grade Prostatic Intra-Epithelial Neoplasia: SWOG S9917. Cancer Prevention Research, 4, 1761-1769. http://dx.doi.org/10.1158/1940-6207.CAPR-10-0343

[29] Algotar, A.M., Stratton, M.S., Ahmann, F.R., Ranger-Moore, J., Nagle, R.B., Thompson, P.A., et al. (2013) Phase 3 Clinical Trial Investigating the Effect of Selenium Supplementation in Men at High Risk of Prostate Cancer. Prostate, 73, 328-335. http://dx.doi.org/10.1002/pros.22573

[30] Ulrike, P. and Takata, Y. (2008) Selenium and the Prevention of Prostate and Colorectal Cancer. Molecular Nutrition and Food Research, 52, 1261-1272. http://dx.doi.org/10.1002/mnfr.200800103

[31] Netke, S.P., Roomi, M.W., Ivanov, V., Niedzwiecki, A. and Rath, M. (2003) A Specific Combination of Ascorbic Acid, Lysine, Proline and Epigallocatechin Gallate Inhibits Proliferation of Extracellular Matrix Invasion of Various Human Cancer Cell Lines. Research Communications in Pharmacology and Toxicology: Emerging Drugs, 2, 37-50.

[32] Roomi, W., Roomi, N., Kalinovsky, T., Niedzwiecki, A. and Rath, M. (2010) In Vivo and In Vitro Effect of a Nutrient Mixture on Human Hepatocarcinoma Cell Line SK-HEP-1. Experimental Oncology, 32, 84-91. 
[33] Roomi, W., Kalinovsky, T., Cha, J., Roomi, N., Niedzwiecki, A. and Rath, M. (2014) Effects of a Nutrient Mixture on Immunohistochemical Localization of Cancer Markers in Human Cervical Cancer HeLa Cell Tumor Xenografts in Female Nude Mice. Experimental and Therapeutic Medicine. (In Press)

[34] Roomi, W., Ivanov, V., Kalinovsky, T., Niedzwiecki, A. and Rath, M. (2005) In Vivo Anti-Tumor Effect of Ascorbic Acid, Lysine, Proline and Green Tea Extract on Human Colon Cancer Cell HCT 116 Xenografts in Nude Mice: Evaluation of Tumor Growth and Immunohistochemistry. Oncology Reports, 13, 421-425.

[35] Roomi, W., Ivanov, V., Kalinovsky, T., Niedzwiecki, A. and Rath, M. (2005) In Vitro and in Vivo Anti-Tumorigenic Activity of Lysine, Proline, Ascorbic Acid and Green Tea Extract on Human Breast Cancer Cell Lines MDA-MB-231 and MCF7. Medical Oncology, 22, 129-138. http://dx.doi.org/10.1385/MO:22:2:129

[36] Roomi, W., Ivanov, V., Netke, S., Kalinovsky, T., Niedzwiecki, A. and Rath, M. (2006) In Vivo and in Vitro Anti-Tumor Effect of Ascorbic Acid, Lysine, Proline and Green Tea Extract on Human Melanoma Cell Line A2058. In Vivo, 20, 25-32.

[37] Roomi, W., Ivanov, V., Kalinovsky, T., Niedzwiecki, A. and Rath, M. (2007) Inhibition of Cell Invasion and MMP Production by a Nutrient Mixture in Malignant Liposarcoma Cell Line SW-872. Medical Oncology, 24, 394-401. http://dx.doi.org/10.1007/s12032-007-0022-z

[38] Roomi, W., Ivanov, V., Kalinovsky, T., Niedzwiecki, A. and Rath, M. (2005) Anti-Tumor Effect of Nutrient Synergy on Human Osteosarcoma Cells U-2OS, MNNG-HOS and Ewing's Sarcoma SK-ES.1. Oncology Reports, 13, $253-257$.

[39] Roomi, W., Ivanov, V., Kalinovsky, T., Niedzwiecki, A. and Rath, M. (2004) Anti-Tumor Effect of Ascorbic Acid, Lysine, Proline, Arginine, and Epigallocatechin Gallate on Prostate Cancer Cell Lines PC-3, LNCaP, and DU-145. Research Communications in Molecular Pathology and Pharmacology, 115-116, 251-264.

[40] Roomi, M.W., Ivanov, V., Netke, S.P., Niedzwiecki, A. and Rath, M. (2003) Serum Markers of the Liver, Heart, and Kidney and Lipid Profile and Histopathology in ODS Rats Treated with Nutrient Synergy. Journal of the American College of Nutrition, 22, 477. 
Scientific Research Publishing (SCIRP) is one of the largest Open Access journal publishers. It is currently publishing more than 200 open access, online, peer-reviewed journals covering a wide range of academic disciplines. SCIRP serves the worldwide academic communities and contributes to the progress and application of science with its publication.

Other selected journals from SCIRP are listed as below. Submit your manuscript to us via either submit@scirp.org or Online Submission Portal.
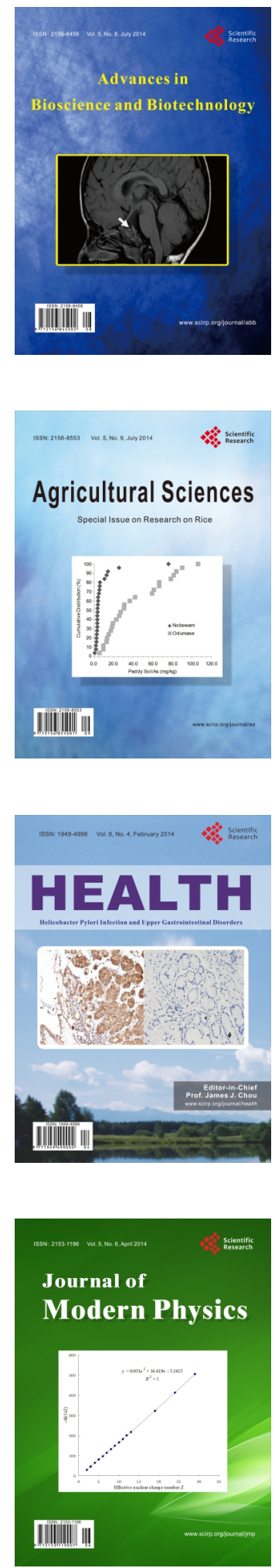
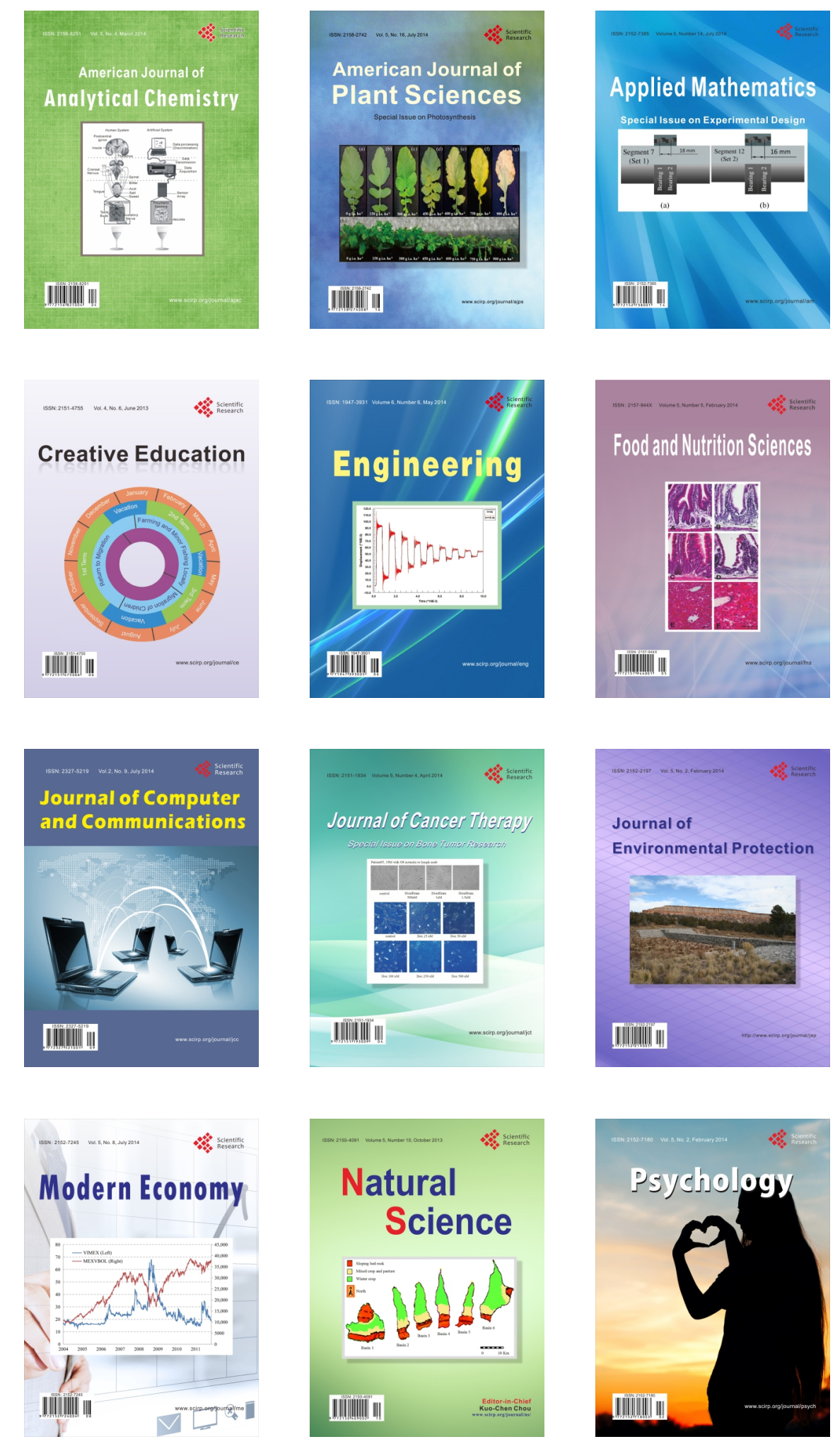